\title{
Hubungan Mutu Pelayanan Terhadap Kepuasan Pasien : Studi Kasus Pasien Rawat Inap Rumah Sakit Umum Kabupaten Bombana 2021
}

\author{
Salfia, Sartiah Yusran², Juminten Saimin ${ }^{3}$ \\ Jurusan Kesehatan Masyarakat, Program Pascasarjana, Universitas Halu Oleo, Kendari, Indonesia \\ salfia.sauba@gmail.com
}

\begin{abstract}
Abstrak
Studi ini bertujuan untuk menganalisis Kepuasan Pasien Di BLUD Rumah Sakit Umum Kabupaten Bombana yang di tinjau dari aspek model service quality (kehandalan, jaminan, bukti fisik, perhatian dan daya tanggap). Penelitian ini merupakan penelitian kuantitatif, dengan rancangan cross sectional study. Teknik pengumpulan data menggunakan angket dan hasilnya menunjukan bahwa terdapat hubungan yang bermakna antara reliability, Assurance, tangible, empathy dan responsiviness dengan kepuasan pasien, dengan nilai $(\rho$ value $=0.000<0,05)$. Dapat disimpulkan bahwa, aspek kehandalan, jaminan, bukti fisik, perhatian dan daya tanggap petugas dalam memberikan pelayanan dan edukasi kepada pasien di BLUD Rumah Sakit Umum Kabupaten Bombana dapat mempengaruhi tingkat kepuasan pasien. Pada penelitian ini ditemukan pula jaminan dan empathy menjadi kriteria yang lebih dominan terhadap penilaian kepuasan pasien.
\end{abstract}

Kata Kunci : Mutu layanan, Kepuasan Pasien, Rawat Inap

\section{Abstract}

This study analyzes Patient Satisfaction at the BLUD General Hospital Bombana Regency in terms of service quality model aspects (reliability, assurance, physical evidence, attention, and responsiveness. This research is a quantitative study with a cross-sectional study design-data collection techniques using a questionnaire. The results showed a significant relationship between reliability, assurance, tangibles, empathy, and responsiveness with patient satisfaction with a value ( $\rho$ value $=0.000<0.05$ ). From the study results, it was concluded that from the aspect of reliability, assurance, physical evidence, attention, and responsiveness of officers in providing services and education to patients at the BLUD of Bombana District General Hospital, it could affect the level of patient satisfaction. In this study, assurance and empathy become the dominant criteria for assessing patient satisfaction

Keywords: Quality of service, Patient Satisfaction, Hospitalization

\section{PENDAHULUAN}

Pelayanan kesehatan menurut WHO (World Health Organization) adalah bagian integral dari suatu organisasi sosial dan kesehatan dengan fungsi menyediakan pelayanan paripurna, penyembuhan penyakit dan pencegahan penyakit kepada masyarakat[1]. Undang - Undang RI Nomor 44 Tahun 2009, rumah sakit adalah institusi pelayanan kesehatan yang menyelenggarakan pelayanan kesehatan perorangan secara paripurna yang menyediakan pelayanan rawat inap, rawat jalan, dan gawat darurat. Pelayanan tugas kesehatan perorangan secara paripurna tersebut, pada dasarnya rumah sakit mempunyai fungsi menyelenggarakan pelayanan pengobatan dan pemulihan kesehatan sesuai dengan standar pelayanan rumah sakit[2].

Menurut Hardiyansyah[3] \& Rinala, dkk[4] pelayanan berkualitas atau memuaskan bila pelayanan tersebut dapat memenuhi kebutuhan dan harapan masyarakat. Karena itu, kualitas pelayanan sangat penting dan selalu focus kepada kepuasan pelanggan.

Menurut Tjiptono [5], kualitas pelayanan menjadi indikator kinerja bagi penyelenggara pelayanan kesehatan. Terdapat berbagai ukuran untuk menilai kualitas pelayanan. Menurut Parasuraman dkk[6] \& Kotler[7] ada lima dimensi utama kualitas pelayanan sesuai urutan derajat kepentingan relatifnya yaitu (1) Keandalan (Realibility) yaitu kemampuan memberikan pelayanan yang dijanjikan dengan segera, akurat, dan memuaskan (2) Daya Tanggap (Responsiveness) yaitu keinginan para staf untuk membantu pelanggan dan memberikan layanan dengan tanggap, (3) Jaminan (Assurance) mencakup pengetahuan, kompetensi, kesopanan dan sifat dapat dipercaya yang dimliki para staf; bebas dari bahaya, risiko atau keragu-raguan (4) Empati (Empathy) meliputi kemudahan dalam menjalin relasi, komunikasi yang baik, perhatian pribadi, dan pemahaman atas kebutuhan individual pada pelanggan 
(5) Bukti Fisik (Tangible) meliputi fasilitas fisik, perlengkapan, pegawai dan sarana komunikasi.

Pengguna jasa pelayanan rumah sakit dalam hal ini pasien menuntut pelayanan yang berkualitas tidak hanya menyangkut kesembuhan dari penyakit secara fisik atau meningkatkan derajat kesehatannya, tetapi juga menyangkut kepuasan terhadap sikap, selalu tersedianya sarana dan prasarana yang memadai dan lingkungan fisik yang dapat memberikan kenyamanan. Kepuasan pasien tergantung pada kualitas pelayanan yang diberikan. Pasien yang loyal akan menggunakan kembali pelayanan kesehatan yang sama bila mereka membutuhkan kembali. Bahkan pasien loyal akan mengajak orang lain untuk menggunakan fasilitas pelayanan kesehatan yang sama [8].

Suatu pelayanan dikatakan baik oleh pasien, ditentukan oleh kenyataan apakah jasa yang diberikan bias memenuhi kebutuhan pasien, dengan menggunakan persepsi pasien tentang pelayanan yang diterima (memuaskan atau mengecewakan, juga termasuk lamanya waktu pelayanan)[9]. Kepuasan dimulai dari penerimaan terhadap pasien dari pertama kali datang, sampai pasien meninggalkan rumah sakit[10]. Untuk pencapaian kepuasan pasien tentu saja dengan melakukan upaya penyelenggaraan pelayanan kesehatan di institusi kesehatan yang berkualitas. Kepuasan pasien menjadi tantangan besar dalam pemberian pelayanan kesehatan saat ini.

Berdasarkan data profil BLUD Rumah Sakit Umum Kabupaten Bombana tahun 2020 memiliki visi sebagai rumah sakit unggulan dan berkualitas bagi masyarakat bombana dan sekitarnya "(Renstra 2017 - 2022). Yang tertuang dalam misi, nilai-nilai serta norma yaitu menyelenggarakan pelayanan kesehatan yang prima dan terjangkau, meningkatkan sumber daya dan profesionalisme petugas melalui pendidikan dan pelatihan, dan mengupayakan peningkatan pembangunan fisik berkesinambungan dan terpadu sesuai standar pelayanan kesehatan. BLUD Rumah Sakit Umum Kabupaten Bombana sebagai Rumah Sakit sarana pelayanan kesehatan milik pemerintah Kabupaten Bombana. Dalam menjalankan kebijakan penyelenggaraan pelayanan kesehatan Rumah Sakit Umum Kabupaten Bombana memiliki berbagai sarana pelayanan kesehatan diantaranya pelayanan perawatan Obgyn, perawatan interna, perawatan anak/bayi, perawatan bedah, perawatan kelas 1 dan 2, dan Perawatan ICU.

BLUD Rumah Sakit Umum Kabupaten Bombana merupakan rumah sakit tingkat rujukan primer dari puskesmas atau sarana kesehatan lainnya yang ada diwilayah kabupaten bombana maupun di luar kabupaten bombana dan harus memiliki pelayanan yang bermutu dan petugas yang profesional. Pelayanan kesehatan berbagai instalasi khususnya pelayanan di Instalasi unit rawat inap harus dapat memuaskan setiap pemakai jasa pelayanan sesuai dengan tingkat kepuasan rata-rata pasien dan penyelenggaraannya sesuai dengan kode etik dan standar pelayanan yang diterapkan. Ini dapat dilihat dari pelayanan dokter dan perawat dengan pembagian jam disesuaikan dengan instalasi rawat inap.

Berdasarkan data kunjungan di BLUD Rumah Sakit Umum Kabupaten Bombana per tiga bulan terakhir tahun 2021 sebanyak 615 pasien terdiri dari perawatan OBGYN sebanyak 243 pasien, perawatan interna sebanyak 74 pasien, perawatan bayi/anak sebayak 171 pasien, perawatan bedah sebanyak 79 pasien, perawatan kelas 41 pasien dan perawatan ICU sebanyak 7 pasien. Ini lebih rendah kunjunan dari tahun 2019 yaitu sebanyak 2876 pasien rawat inap dengan jumlah rata-rata pengunjung tiap bulannya sebanyak 286 pasien dan tahun 2020 jumlah kunjungan sebanyak 2783 pasien rawat inap dengan jumlah rata-rata pengunjung tiap bulannya sebanyak 232 pasien.

Untuk kunjungan pasien di unit rawat inap, baik kunjungan pasien baru maupun kunjungan pasien lama mengalami penurunan. Ini menunjukkan bahwa tingkat loyalitas pasien di BLUD Rumah Sakit Umum Kabupaten Bombana mengalami penurunan. Ini dipengaruhi berbagai factor baik faktor internal maupun factor eksternal. Faktor internal terdiri dari mutu pelayanan kesehatan yang belum berjalan secara optimal sesuai dengan standar pelayanan kesehatan, ini dapat dilihat dari masih banyak masyarakat Kabupaten Bombana memperbandingkan dengan kualitas pelayanan kesehatan diwilayah lain seperti Kolaka dan kendari. Faktor eksternal seperti jarak antara rumah sakit dengan tempat tinggal, transportasi, harga, dan informasi.

Jika kinerja layanan kesehatan yang diperoleh pasien pada suatu fasilitas layanan kesehatan sesuai dengan harapannya, pasien pasti akan selalu dating berobat kefasilitas layanan kesehatan tersebut. Pasien akan selalu mencari pelayanan kesehatan di fasilitas yang kinerja pelayanan kesehatannya dapat memenuhi harapan atau tidak mengecewakan pasien[11]. Kenyataan menunjukkan bahwa pasien yang tidak puasakan memberikan rekomendasi dari mulut kemulut, sehingga mempengaruhi sikap dan keyakinan orang lain untuk tidak berkunjung kesarana tersebut [5].

Berdasarkan latar belakang diatas, peneliti tertarik untuk melihat kualitas mutu pelayanan kesehatan di 
BLUD Rumah Sakit Kabupaten Bombana dalam hal kepuasan pasien. Kajian ini diharapkan dapat menjadi masukan bagi pihak rumah sakit milik pemerintah di kabupaten Bombana dalam rangka peningkatan kinerja dan mutu pelayanan kesehatan yang menyangkut kepuasan pasien rawat inap.

\section{METODE}

Desain penelitian ini menggunakan penelitian kuantitatif, dengan rancangan cross sectional study sebagai rancangannya. Penelitian ini menggunakan skala likert yaitu suatu pengukuran yang digunakan untuk mengukur sikap, pendapat dan persepsi seseorang atau kelompok tentang fenomena sosial

\section{Lokasi dan Waktu}

Lokasi penelitian ini dilakukan di BLUD Rumah

Sakit Umum Kabupaten Bombana dan pengumpulan data dilakukan bulan Maret - April 2021

Populasi dan Sampel

Populasi dalam penelitian ini adalah seluruh pasien di unit rawat inap BLUD Rumah Sakit Kabupaten Bombana selama tiga bulan terakhir tahun 2021 sesuai dengan kriteria penelitian yakni berjumlah 616 pasien. Sedangkan untuk sampel penilitian terdiri dari 24 Orang dari Instalasi Obgyn, 11 Orang Interna, 24 Orang Bayi/anak, 11 orang Bedah, 6 Orang kelas dan 1 orang ICU yang dperoleh secara proporsional.

Teknik Pengumpulan Data

Dalam penelitian ini teknik pengumpulan data melalui data primer yaitu dengan membagikan kuesioner kepada responden. Kuisioner ini terdiri dari 30 pertanyaan.

\section{Teknik Analisis Data}

Teknik analisis terdiri dari analisis Univariat dan Analisis Bivariat. Analisis univariat dalam bentuk Analisis deskriptif dilakukan dengan membuat tabel dan distribusi frekuensi dari masing-masing variable bebas dan terikat, yaitu Reability, Assurance, Tangible, Empat, Responsiveness dan Kepuasan.

Untuk analisis Bivariat dilakukan terhadap dua variabel yang diduga berhubungan atau berkolerasi, yaitu dengan Reability (Kehandalan), Assurance (Jaminan), Tangible (Bukti Langsung/ Berwujud), Emphaty (Empati), Responsiveness (Daya Tanggap) terhadap Kepuasan dengan menggunakan uji statistic Chi Square yang dilakukan secara komputerisasi. Menurut Riyanto[12] batas atau tingkat kemaknaan yang digunakan dalam penelitian ini yaitu nilai $\alpha 0,05$. Apabila nilai ( $p$ value) $\leq 0,05$ maka perhitungan tersebut dinyatakan bermakna atau ada hubungan antara dua variabel yang dianalisis, tetapi jika nilai ( $p$ value) $>0,05$ maka perhitungan tersebut dinyatakan tidak bermakna atau tidak ada hubungan antar dua variabel yang dianalisis.

\section{Variabel Penelitian}

Variabel penelitian disajikan sebagai pada Gambar 1.

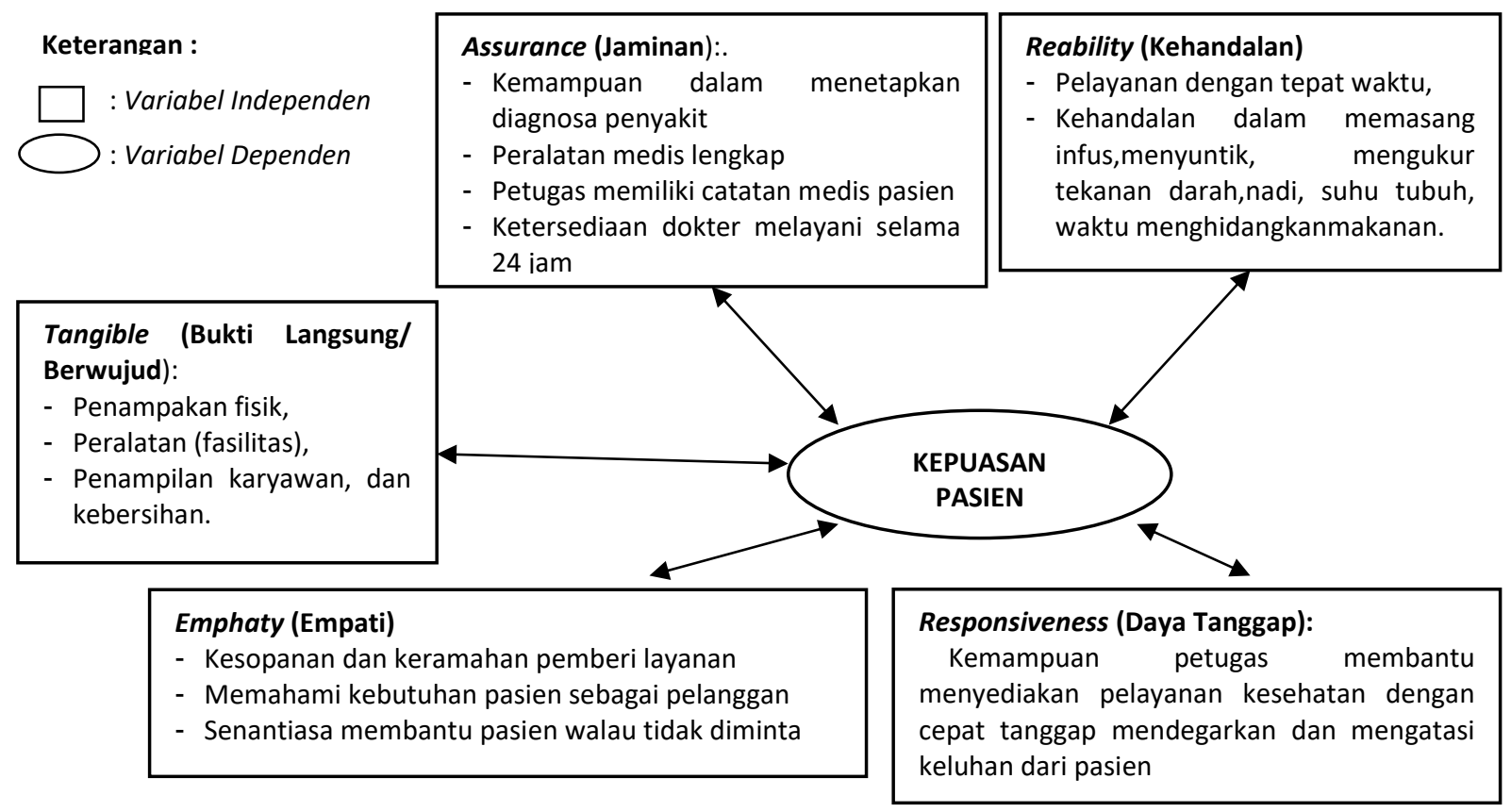

Gambar 1 Variabel penelitian 


\section{Hipotesis Penelitian}

penyusunan hipotesis dapat didefinisikan sebagai hubungan yang diperkirakan secara logis diantara dua atau lebih variabel yang diungkapkan dalam bentuk pernyataan yang bisa diuji. Berikut hipotesisi penelitian yang diajukan dalam kajian ini: (1) Ada hubungan Realibilty (kehandalan) dengan kepuasan pasien rawat inap di BLUD Rumah Sakit Kabupaten Bombana; (2). Ada hubungan Assuarance (Jaminan) dengan kepuasan pasien rawat inap di BLUD Rumah Sakit Kabupaten Bombana; (3). Ada hubungan Tangible (Bukti Langsung) dengan kepuasan pasien rawat inap di BLUD Rumah Sakit Kabupaten Bombana; (4). Ada hubungan Emphaty (Empati) dengan kepuasan pasien rawat inap di BLUD Rumah Sakit Kabupaten Bombana; (5). Ada Hubungan Responsiveness (Daya Tanggap) dengan kepuasan pasien rawat inap di BLUD Rumah Sakit Kabupaten Bombana

HASIL

Dari hasil penelitian tentang hubungan mutu pelayanan terhadap kepuasan pasien rawat inap Di BLUD Rumah Sakit Umum Kabupaten Bombana Tahun 2021 dibagi dalam dua bentuk yaitu analisis univariat dan analisis bivariate.

Analisis univariat merupakan analisis yang bertujuan untuk memberikan gambaran dalam bentuk distribusi umum, distribusi frekuensi dari karakteristik umum responden dan variabel yang diteliti. Karakteristik umum pada peneliti ini adalah Umur, Jenis Kelamin, Pekerjaan, Pendidikan. Sedangkan Variabel yang diteliti adalah Kehandalan (Reability), Jaminan (Assurance), Bukti Fisik (Tangible), Perhatian (Empaty), Daya Tanggap, Kepuasan.

Jenis Kelamin Responden

Distribusi frekuensi responden berdasarkan jenis kelamin di kelompokan seperti pada Tabel 1.

Tabel 1. Distribusi Frekuensi Responden Berdasarkan jenis kelamin Di BLUD RSUD Kabupaten Bombana.

\begin{tabular}{|c|l|c|c|}
\hline No & $\begin{array}{c}\text { Jenis Kelamin } \\
\text { Responden }\end{array}$ & $\begin{array}{c}\text { Jumlah } \\
\text { (n) }\end{array}$ & $\begin{array}{c}\text { Persentase } \\
\text { (\%) }\end{array}$ \\
\hline 1 & Laki-laki & 28 & 32.2 \\
\hline 2 & Perempuan & 59 & 67.8 \\
\hline $\mathbf{3}$ & Total & $\mathbf{8 7}$ & $\mathbf{1 0 0 . 0}$ \\
\hline
\end{tabular}

Berdasarkan Tabel 1 terlihat distribusi frekuensi jenis kelamin dari 87 responden yang paling banyak adalah jenis kelamin perempuan sebanyak 59 orang $(67.8 \%)$ dan jenis kelamin laki-laki sebanyak 28 orang (32.2\%).

Kelompok Usia Responden
Distribusi frekuensi responden berdasarkan kelompok usia menurut Depkes RI (2009).

Tabel 2. Distribusi Frekuensi Responden Berdasarkan Kelompok Usia Di BLUD RSUD Kabupaten Bombana

\begin{tabular}{|c|c|c|c|}
\hline No & $\begin{array}{c}\text { Kelompok Umur } \\
\text { Responden }\end{array}$ & $\begin{array}{c}\text { Jumlah } \\
\text { (n) }\end{array}$ & $\begin{array}{c}\text { Persentase } \\
\text { (\%) }\end{array}$ \\
\hline 1 & $17-25$ (Remaja Akhir) & 20 & 23.0 \\
\hline 2 & $26-35$ (Dewasa Awal) & 25 & 28.8 \\
\hline $\mathbf{3}$ & $36-45$ (Dewasa Akhir) & 20 & 23.0 \\
\hline $\mathbf{4}$ & $46-55$ (Lansia Awal) & 22 & 25.2 \\
\hline & Total & $\mathbf{8 7}$ & $\mathbf{1 0 0 . 0}$ \\
\hline
\end{tabular}

Tabel 2 menunjukkan distribusi frekuensi kelompok usia menunjukkan dari 87 responden yang paling banyak adalah berumur 26-35 tahun yaitu sebanyak 25 orang (28.8\%) dan yang paling sedikit adalah berumur 17-25 tahun dan 36-45 tahun yaitu sebanyak masing-masing 20 orang (23,0\%). Rentang umur responden pada penelitian ini adalah dari umur 17-50 tahun. Hal ini menunjukkan bahwa responden yang sudah berusia produktif lebih rentan di rawat di rumah sakit dan cenderung memanfaatkan pelayanan kesehatan

\section{Pendidikan Terakhir}

Distribusi frekuensi responden berdasarkan pedidikan terakhir di kelompokan (Tabel 3)

Tabel 3 Distribusi Frekuensi Responden Berdasarkan pendidikan terakhir Di BLUD RSUD Kabupaten Bombana.

\begin{tabular}{|c|l|c|c|}
\hline No & \multicolumn{1}{|c|}{$\begin{array}{c}\text { Pendidikan } \\
\text { Responden }\end{array}$} & $\begin{array}{c}\text { Jumlah } \\
\text { (n) }\end{array}$ & $\begin{array}{c}\text { Persentase } \\
(\mathbf{\%})\end{array}$ \\
\hline 1 & S2 & 1 & 1.1 \\
\hline 2 & S1 & 11 & 12.6 \\
\hline $\mathbf{3}$ & D3 & 3 & 3.4 \\
\hline $\mathbf{4}$ & SLTA/SEDERAJAT & 31 & 35.6 \\
\hline $\mathbf{5}$ & SLTP/SEDERAJAT & 8 & 9.2 \\
\hline $\mathbf{6}$ & SD/SEDERAJAT & 33 & 37.9 \\
\hline $\mathbf{7}$ & Total & $\mathbf{8 7}$ & $\mathbf{1 0 0 . 0}$ \\
\hline
\end{tabular}

Tabel 3 menampilkan frekuensi pendidikan menunjukkan bahwa dari 87 responden yang paling banyak adalah tamat SD/Sederajat sebanyak 33 orang (37.9\%) disusul SLTA sebanyak 31 orang $(35,6 \%)$ dan yang paling sedikit adalah Strata 2 (S2) yaitu sebanyak 1 orang $(1.1 \%)$ disusul oleh D3 terdapat 3 orang atau sebesar 3.4\%. Hal ini menunjukkan bahwa kesadaran masyarakat untuk berobat tidak lagi berpengaruh terhadap tingkat pendidikan. Distribusi frekuensi responden berdasarkan Agama (Tabel 4)

Tabel 4 Distribusi Frekuensi Responden Berdasarkan agama Di BLUD RSUD Kabupaten Bombana. 


\begin{tabular}{|c|l|c|c|}
\hline No & \multicolumn{1}{|c|}{$\begin{array}{c}\text { Agama } \\
\text { Responden }\end{array}$} & $\begin{array}{c}\text { Jumlah } \\
\text { (n) }\end{array}$ & $\begin{array}{c}\text { Persentase } \\
(\mathbf{\%})\end{array}$ \\
\hline 1 & Islam & 86 & 98.9 \\
\hline 2 & Kristen & 1 & 1.1 \\
\hline $\mathbf{3}$ & Total & $\mathbf{8 7}$ & $\mathbf{1 0 0 . 0}$ \\
\hline
\end{tabular}

Berdasarkan Tabel 4 distribusi frekuensi agama dari 87 responden yang paling banyak adalah agama Islam sebanyak 86 orang (98.9\%) dan yang paling sedkit adalah agama Kristen yaitu sebanyak 1 orang (1.1\%).

\section{Pekerjaan}

Tabel 5 Responden Berdasarkan pekerjaan Di BLUD RSUD Kabupaten Bombana.

\begin{tabular}{|c|l|c|c|}
\hline No & $\begin{array}{c}|c| \\
\text { Pekerjaan } \\
\text { Responden }\end{array}$ & $\begin{array}{c}\text { Jumlah } \\
(\mathbf{n})\end{array}$ & $\begin{array}{c}\text { Persentase } \\
(\mathbf{\%})\end{array}$ \\
\hline 1 & PNS & 11 & 12.6 \\
\hline 2 & PHL & 4 & 4.6 \\
\hline 3 & Pegawai Swasta & 2 & 2.3 \\
\hline 4 & Wiraswasta & 7 & 8.0 \\
\hline 5 & Mahasiswa & 1 & 1.1 \\
\hline $\mathbf{6}$ & Petani & 17 & 19.5 \\
\hline $\mathbf{7}$ & Nelayan & 5 & 5.7 \\
\hline $\mathbf{8}$ & IRT & 40 & 46.0 \\
\hline $\mathbf{9}$ & Total & $\mathbf{8 7}$ & $\mathbf{1 0 0 . 0}$ \\
\hline
\end{tabular}

Tabel 5 distribusi frekuensi pekerjaan menunjukkan bahwa dari 87 responden yang paling banyak adalah Ibu Rumah Tangga (IRT) sebanyak 40 orang (46.0\%) disusul Petani sebanyak 17 orang (19,5\%) dan yang paling sedikit adalah mahasiswa yaitu sebanyak 1 orang $(1,1 \%)$ disusul Nelayan sebanyak 5 orang $(5,7 \%)$. Hal ini menunjukkan bahwa ibu rumah tangga tingkat kepedulian dengan pentingnya kesehatan sudah lebih tinggi dan banyaknya pasien ibu yang melahirkan di tahun 2021 yang memanfaatkan pelayanan kesehatan.

\section{Reability}

Tabel 6 Frekuensi Responden Berdasarkan kehandalan (Reability) Di BLUD RSUD Kabupaten Bombana.

\begin{tabular}{|c|l|c|c|}
\hline No & $\begin{array}{c}\text { Kehandalan } \\
\text { (Reability) }\end{array}$ & $\begin{array}{c}\text { Jumlah } \\
\text { (n) }\end{array}$ & $\begin{array}{c}\text { Persentase } \\
(\mathbf{\%})\end{array}$ \\
\hline 1 & Baik & 71 & 81.6 \\
\hline 2 & Kurang Baik & 16 & 18.4 \\
\hline 3 & Total & $\mathbf{8 7}$ & $\mathbf{1 0 0 . 0}$ \\
\hline
\end{tabular}

Berdasarkan Tabel 6 distribusi frekuensi kehandalan (Reability) petugas kesehatan dari 87 responden sebanyak 71 responden (81.6\%) menyatakan petugas kesehatan memiliki kehandalan (Reability) yang baik dan sebanyak 16 responden (18.4\%) yang menyatakan petugas kesehatan memiliki kehandalan (Reability) yang kurang baik.

http://ejournal.urindo.ac.id/index.php/MARSI

\section{Assurance}

Tabel 7 Frekuensi Responden Berdasarkan kehandalan (Reability) Di BLUD RSUD Kabupaten Bombana.

\begin{tabular}{|c|l|c|c|}
\hline No & $\begin{array}{c}\text { Jaminan } \\
\text { (Assurance) }\end{array}$ & $\begin{array}{c}\text { Jumlah } \\
\text { (n) }\end{array}$ & $\begin{array}{c}\text { Persentase } \\
\text { (\%) }\end{array}$ \\
\hline 1 & Baik & 80 & 92.0 \\
\hline 2 & Kurang Baik & 7 & 8.0 \\
\hline $\mathbf{3}$ & Total & $\mathbf{8 7}$ & $\mathbf{1 0 0 . 0}$ \\
\hline
\end{tabular}

Tabel 7 distribusi frekuensi jaminan (assurance) petugas kesehatan dari 87 responden sebanyak 80 responden (92.0\%) menyatakan petugas kesehatan memiliki jaminan (assurance) yang baik dan sebanyak 7 responden (8.0\%) yang menyatakan petugas kesehatan memiliki kehandalan (assurance) yang kurang baik.

Tangible

Distribusi frekuensi responden berdasarkan Bukti Fisik (Tangible) (Tabel 8)

Tabel 8 Distribusi Frekuensi Responden Berdasarkan Bukti Fisik (Tangible) Di BLUD RSUD Kabupaten Bombana

\begin{tabular}{|c|l|c|c|}
\hline No & \multicolumn{1}{|c|}{$\begin{array}{c}\text { Bukti Fisik } \\
\text { (Tangible) }\end{array}$} & $\begin{array}{c}\text { Jumlah } \\
\text { (n) }\end{array}$ & $\begin{array}{c}\text { Persentase } \\
\text { (\%) }\end{array}$ \\
\hline 1 & Baik & 73 & 83.9 \\
\hline 2 & Kurang Baik & 14 & 16.1 \\
\hline 3 & Total & 87 & 100.0 \\
\hline
\end{tabular}

Distriusi frekuensi bukti fisik (tangible) (Tabel 8) petugas kesehatan dari 87 responden sebanyak 73 responden (83.9\%) menyatakan petugas kesehatan memiliki bukti fisik (tangible) yang baik dan sebanyak 14 responden (16.1\%) yang menyatakan petugas kesehatan memiliki bukti fisik (tangible) yang kurang baik.

Empaty

Tabel 9 Distribusi Frekuensi Responden Berdasarkan Perhatian (Empaty) di BLUD RSUD Kabupaten Bombana

\begin{tabular}{|c|l|c|c|}
\hline No & $\begin{array}{c}\text { Perhatian } \\
\text { (Empaty) }\end{array}$ & $\begin{array}{c}\text { Jumlah } \\
\text { (n) }\end{array}$ & $\begin{array}{c}\text { Persentase } \\
\text { (\%) }\end{array}$ \\
\hline 1 & Baik & 74 & 85.1 \\
\hline 2 & Kurang Baik & 13 & 14.9 \\
\hline $\mathbf{3}$ & Total & 87 & 100.0 \\
\hline
\end{tabular}

Berdasarkan Tabel 9 distribusi frekuensi perhatian (empaty) petugas kesehatan dari 87 responden sebanyak 74 responden $(85.1 \%)$ menyatakan petugas kesehatan memiliki perhatian (empaty) yang baik dan sebanyak 13 responden (14.9\%) yang menyatakan petugas kesehatan memiliki perhatian (empaty) yang kurang baik.

\section{Daya Tanggap}

Tabel 10 Distribusi Frekuensi Responden Berdasarkan Daya Tanggap Di BLUD RSUD Kabupaten Bombana.

\begin{tabular}{|c|c|c|c|}
\hline No & $\begin{array}{c}\text { Daya } \\
\text { Tanggap }\end{array}$ & $\begin{array}{c}\text { Jumlah } \\
(\mathrm{n})\end{array}$ & $\begin{array}{c}\text { Persentase } \\
(\%)\end{array}$ \\
\hline
\end{tabular}




\begin{tabular}{|c|l|c|c|}
\hline 1 & Baik & 72 & 82.8 \\
\hline 2 & Kurang Baik & 15 & 17.2 \\
\hline 3 & Total & 87 & 100.0 \\
\hline
\end{tabular}

Tabel 10 distribusi frekuensi daya tanggap petugas kesehatan dari 87 responden sebanyak 72 responden (82.8\%) menyatakan petugas kesehatan memiliki daya tanggap yang baik dan sebanyak 15 responden (17.2\%) yang menyatakan petugas kesehatan memiliki daya tanggap yang kurang baik.

Kepuasan

Tabel 10 Frekuensi Responden Berdasarkan Kepuasan di BLUD RSUD Kabupaten Bombana.

\begin{tabular}{|c|l|c|c|}
\hline No & Kepuasan & $\begin{array}{c}\text { Jumlah } \\
\text { (n) }\end{array}$ & $\begin{array}{c}\text { Persentase } \\
\text { (\%) }\end{array}$ \\
\hline 1 & Puas & 70 & 80.5 \\
\hline 2 & Kurang Puas & 17 & 19.5 \\
\hline $\mathbf{3}$ & Total & $\mathbf{8 7}$ & $\mathbf{1 0 0 . 0}$ \\
\hline
\end{tabular}

Berdasarkan Tabel 10 distribusi frekuensi kepuasan pelayanan kesehatan dari 87 responden sebanyak 70 responden (80.5\%) menyatakan puas terhadap pelayanan petugas dan sebanyak 17 responden (19.5\%) yang menyatakan kurang puas terhadap pelayanan petugas.

Selanjutnya, Analisis Bivariat dilakukan untuk melihat hubungan antara variabel independen Reability, Assurance, Tangible, Emphaty, Daya Tanggap dengan variable dependen (Kepuasan Pasien).

Hubungan Kehandalan (Reabilitiy) dengan kepuasan pelayanan kesehatan rawat inap di BLUD RSUD Kabupaten Bombana

Hasil analisis penelitian menunjukan bahwa Hubungan Kehandalan (Reabilitiy) dengan kepuasan pelayanan kesehatan rawat inap di BLUD RSUD Kabupaten Bombana dapat dilihat Pada Tabel 11.

Tabel 11 Hubungan Kehandalan (Reability) dengan kepuasan pelayanan kesehatan

\begin{tabular}{|c|c|c|c|c|c|}
\hline \multirow{3}{*}{$\begin{array}{l}\text { Kehandalan } \\
\text { (Reability) }\end{array}$} & \multicolumn{4}{|c|}{ Kepuasan } & \multirow{2}{*}{$p$} \\
\hline & \multicolumn{2}{|c|}{ Puas } & \multicolumn{2}{|c|}{ Kurang Puas } & \\
\hline & $\mathbf{N}$ & $\%$ & $\mathbf{N}$ & $\%$ & \multirow{4}{*}{0.000} \\
\hline Baik & 66 & 93.0 & 5 & 7.0 & \\
\hline Kurang Baik & 4 & 25.0 & 12 & 75.0 & \\
\hline Total & 70 & 80.5 & 17 & 19.5 & \\
\hline
\end{tabular}

Berdasarkan Tabel 11 menunjukan bahwa responden yang menyatakan merasa puas dengan petugas kesehatan yang memiliki Kehandalan (reability) yang baik sebesar 66 responden (93.0\%) lebih besar dibandingkan dengan petugas kesehatan yang memiliki kehandalan (reability) kurang baik sebesar 4 responden
(25.0\%), sementara responden yang menyatakan kurang puas dengan petugas kesehatan yang memiliki kehandalan (reability) baik sebesar 5 responden (7.0\%) lebih kecil dibandingkan dengan petugas kesehatan yang memiliki kehandalan (reability) kurang baik sebesar 12 responden (75.0\%)

Berdasarkan uji statistik Chi Square memperlihatkan nilai $\rho$ value $=0.000<0,05$ maka $\mathrm{Ha}$ diterima dan $\mathrm{HO}$ ditolak artinya ada hubungan kehandalan (reability) dengan kepuasan pasien terhadap pelayanan kesehatan rawat inap di BLUD RSUD Kabupaten Bombana

Hubungan Jaminan (Assurance) dengan kepuasan pelayanan kesehatan rawat inap di BLUD RSUD Kabupaten Bombana

Hasil penelitian menunjukan bahwa Hubungan Jaminan (Assurance) dengan kepuasan pelayanan kesehatan rawat inap di BLUD RSUD Kabupaten Bombana (Tabel 12).

Tabel 12 Hubungan Jaminan (Assurance) dengan kepuasan pelayanan kesehatan

\begin{tabular}{|c|c|c|c|c|c|}
\hline \multirow{3}{*}{$\begin{array}{c}\text { Jaminan } \\
\text { (Assurance) }\end{array}$} & \multicolumn{4}{|c|}{ Kepuasan } & \multirow{2}{*}{$p$} \\
\hline & \multicolumn{2}{|c|}{ Puas } & \multicolumn{2}{|c|}{ Kurang Puas } & \\
\hline & $\mathbf{N}$ & $\%$ & $\mathbf{N}$ & $\%$ & \multirow{4}{*}{0.000} \\
\hline Baik & 68 & 85.0 & 12 & 15.0 & \\
\hline Kurang Baik & 2 & 28.6 & 5 & 71.4 & \\
\hline Total & 70 & 80.5 & 17 & 19.5 & \\
\hline
\end{tabular}

Tabel 12 menidentifikasin terkait responden responden yang menyatakan merasa puas dengan petugas kesehatan yang memiliki jaminan (assurance) yang baik sebesar 68 responden (85.0\%), lebih besar dibandingkan dengan petugas kesehatan yang memilki jaminan (assurance) kurang baik sebesar 2 responden (28.6\%). Sementara responden yang menyatakan kurang puas dengan petugas kesehatan yang memiliki (assurance) yang baik sebesar 12 responden (15.0\%) lebih besar dibandingkan dengan petugas kesehatan yang memiliki jaminan (assurance) kurang baik sebesar 5 responden (71.4\%). Berdasarkan uji statistik Chi Square memperlihatkan nilai $\rho$ value $=0.000<0,05$ maka $\mathrm{Ha}$ diterima dan $\mathrm{H}_{0}$ ditolak artinya ada hubungan jaminan (assurance) dengan kepuasan pasien terhadap pelayanan kesehatan rawat inap di BLUD RSUD Kabupaten Bombana

Hubungan Bukti Fisik (Tangible) dengan kepuasan pelayanan kesehatan rawat inap di BLUD RSUD Kabupaten Bombana 
Tabel 13 Hubungan Bukti Fisik (Tangible) dengan kepuasan pelayanan kesehatan

\begin{tabular}{|l|l|l|l|l|l|}
\hline \multirow{2}{*}{$\begin{array}{c}\text { Bukti Fisik } \\
\text { (Tangible) }\end{array}$} & \multicolumn{4}{|c|}{ Kepuasan } & \multirow{2}{*}{$p$} \\
\cline { 2 - 5 } & \multicolumn{2}{|c|}{ Puas } & \multicolumn{2}{c|}{ Kurang Puas } & \\
\cline { 2 - 5 } & \multicolumn{1}{|c|}{$\mathbf{N}$} & $\mathbf{N}$ & \multicolumn{1}{c|}{ \% } & \\
\hline Baik & 66 & 90.4 & 7 & 9.6 & \multirow{2}{*}{0.00} \\
\hline Kurang Baik & 4 & 28.6 & 10 & 71.4 & \\
\hline Total & 70 & 80.5 & 17 & 19.5 & \\
\hline
\end{tabular}

Dari Tabel 13 menunjukan bahwa responden yang menyatakan merasa puas dengan petugas kesehatan yang memiliki bukti fisik (tangible) yang baik sebesar 66 responden (90.4\%) lebih besar dibandingkan dengan petugas kesehatan yang memiliki bukti fisik (tangible) kurang baik sebesar 4 responden (28.6\%), sementara responden yang menyatakan kurang puas dengan petugas kesehatan yang memiliki bukti fisik (tangible) baik sebesar 7 responden (9.6\%) lebih kecil dibandingkan dengan petugas kesehatan yang memiliki bukti fisik (tangible) kurang baik sebesar 10 responden (71.4\%) Berdasarkan uji statistik Chi Square memperlihatkan nilai $\rho$ value $=0.000<0,05$ maka $\mathrm{Ha}$ diterima dan $\mathrm{HO}$ ditolak artinya ada hubungan Bukti Fisik (Tangible) dengan kepuasan pasien terhadap pelayanan kesehatan rawat inap di BLUD RSUD Kabupaten Bombana.

Hubungan Perhatian (Empaty) dengan kepuasan pelayanan kesehatan rawat inap di BLUD RSUD Kabupaten Bombana

Tabel 14 Hubungan Perhatian (Empaty) dengan kepuasan pelayanan kesehatan

\begin{tabular}{|l|l|l|l|l|l|}
\hline \multirow{2}{*}{$\begin{array}{l}\text { Perhatian } \\
\text { (Empaty) }\end{array}$} & \multicolumn{4}{|c|}{ Kepuasan } & \multirow{2}{*}{$p$} \\
\cline { 2 - 5 } & \multicolumn{2}{|c|}{ Puas } & \multicolumn{2}{c|}{ Kurang Puas } & \\
\cline { 2 - 5 } & $\mathbf{N}$ & $\mathbf{\%}$ & $\mathbf{N}$ & $\mathbf{\%}$ & \\
\hline Baik & 68 & 91.9 & 6 & 8.1 & \multirow{2}{*}{0.000} \\
\hline Kurang Baik & 2 & 15,4 & 11 & 84.6 & \\
\hline Total & 70 & 80.5 & 17 & 19.5 & \\
\hline
\end{tabular}

Tabel 14 melaporkan bahwa responden menyatakan merasa puas dengan petugas kesehatan yang memiliki perhatian (empaty) yang baik sebesar 68 responden (91.9\%) lebih besar dibandingkan dengan petugas kesehatan yang memiliki perhatian (empaty) kurang baik sebesar 2 responden (15.4\%), sementara responden yang menyatakan kurang puas dengan petugas kesehatan yang memiliki perhatian (empaty) baik sebesar 6 responden (8.1\%) lebih kecil dibandingkan dengan petugas kesehatan yang memiliki perhatian (empaty) kurang baik 11 responden (84.6\%) Berdasarkan uji statistik Chi Square memperlihatkan nilai $\rho$ value $=0.000<0,05$ maka $\mathrm{Ha}$ diterima dan $\mathrm{H}_{0}$ ditolak artinya ada hubungan Perhatian (empaty) dengan kepuasan pasien terhadap pelayanan kesehatan rawat inap di BLUD RSUD Kabupaten Bombana.

Hubungan Daya Tanggap dengan kepuasan pelayanan kesehatan rawat inap di BLUD RSUD Kabupaten Bombana

Tabel 15. Hubungan Daya Tanggap dengan kepuasan pelayanan kesehatan

\begin{tabular}{|c|c|c|c|c|c|}
\hline \multirow{3}{*}{$\begin{array}{l}\text { Daya } \\
\text { Tanggap }\end{array}$} & \multicolumn{4}{|c|}{ Kepuasan } & \multirow{2}{*}{$p$} \\
\hline & \multicolumn{2}{|c|}{ Puas } & \multicolumn{2}{|c|}{ Kurang Puas } & \\
\hline & $\mathbf{N}$ & $\%$ & $\mathbf{N}$ & $\%$ & \multirow{4}{*}{0.00} \\
\hline Baik & 66 & 91.7 & 6 & 8.3 & \\
\hline Kurang Baik & 4 & 26.7 & 11 & 73.3 & \\
\hline Total & 70 & 80.5 & 17 & 19.5 & \\
\hline
\end{tabular}

Tabel 15 menunjukkan bahwa responden yang menyatakan merasa puas dengan petugas kesehatan yang memiliki daya tanggap yang baik sebesar 66 responden (93.0\%) lebih besar dibandingkan dengan petugas kesehatan yang memiliki daya tanggap kurang baik sebesar 4 responden (26.7\%) sementara responden yang menyatakan kurang puas dengan petugas kesehatan yang memiliki daya tanggap baik sebesar 6 responden (8.3\%) lebih kecil dibandingkan dengan petugas kesehatan yang memiliki daya tanggap kurang baik sebesar 11 responden (73.3\%) Berdasarkan uji statistik Chi Square memperlihatkan nilai $\rho$ value $=$ $0.000<0,05$ maka $\mathrm{Ha}$ diterima dan $\mathrm{HO}$ ditolak artinya ada hubungan Daya Tanggap dengan kepuasan pasien terhadap pelayanan kesehatan rawat inap di BLUD RSUD Kabupaten Bombana.

\section{DISKUSI}

Hasil analisi hubungan antara kehandalan dengan kepuasan pasien analisis menunjukkan bahwa pasien rawat inap di BLUD Rumah Sakit Daerah Kabupaten Bombana yang menyatakan puas dengan petugas kesehatan yang memiliki kehandalan (reability) yaitu sebesar $71 \%$ dan pasien yang kurang puas dengan petugas yang memiliki kehandalan (reability) sebesar $16 \%$ yang membahas tentang prosedur penerimaan dan pelayanan kepada pasien, perawat yang memberikan informasi kepada pasien sebelum melakukan tindakan keperawatan, petugas yang ramah, kehadiran dokter dan pemeriksaan dokter.

Hasil ini sejalan dengan Niswatul[13] di Puskesmas Blang Geulumpang Kabupaten Aceh Utara didapat hasil terdapat hubungan yang bermakna antara faktor 
kehandalan (reability) dengan kepuasan pasien dengan nilai $\rho$ value $=0.006$. hasil ini menunjukan kehandalan mempunyai pengaruh besar dalam meningkatkan kualitas pelayanan terhadap pasien. Hal yang sama yang dilakukan Saputra dkk,[14] kepada pasien di RSDI Kota Banjarbaru. Hasil penelitian menunjukkan bahwa ada hubungan yang positif antara kehandalan (reability) dengan kepuasan pasien ( $\rho$ value $=0,000$ ), semakin tinggi reliability maka semakin tinggi tingkat kepuasannya. Responden ternyata membutuhkan pelayanan kesehatan berdasarkan keluhan yang dideritanya dan keinginannya untuk sembuh.

Dimensi ini menunjukkan kemampuan untuk memberikan pelayanan dengan sesuai janji yang ditawarkan. Penelitian ini berkaitan dengan ketepatan waktu, pengurus pendaftaran, waktu pengobatan/ pemeriksaan dan memberikan informasi dengan jelas sesuai dengan kebutuhan pasien. Hasil penelitian menunjukkan bahwa pengobatan di Badan Layanan Umum Daerah Rumah Sakit Umum Kabupaten Bombana sebagian besar responden mengakui bahwa perawat selalu memberikan pelayanan sesuai dengan prosedur yang dilakukan oleh perawat. Responden yang menjawab tidak puas dan kurang puas menyatakan bahwa perawat tidak memberikan informasi lebih dahulu dalam pelaksanaan prosedur pelayanan. Hasil penelitian menunjukkan ketepatan jadwal kunjungan dokter di Badan Layanan Umum Daerah Rumah Sakit Umum Kabupaten Bombana responden mengakui bahwa dokter tepat waktu dalam melayani pasien. Responden yang menjawab kurang puas dan kurang baik menyatakan bahwa dokter terutama dokter spesialis tidak tepat waktu dalam pemeriksaan pasien. Latupono dkk melaporkan bahwa Keberhasilan dalam kesembuhan pasien salah satunya adalah ketepatan dalam menentukan diagnosis penyakit, sehingga dapat diberikan obat sesuai dengan penyakit yang dideritanya. Komponen layanan dokter selama pasien menjalani rawat inap merupakan komponen yang strategis. Hubungan pelayanan dokter dengan pasien adalah berdasarkan kepercayaan[15]

Berdasarkan hasil pengamatan dan wawancara yang dilakukan peneliti bahwa pasien yang menyatakan puas kepada petugas kesehatan yang memiliki kehandalan (reability), ini dikarenakan pasien mengalami dan merasakan langsung terhadap pemberian pelayanan kesehatan baik dari kecepatan waktu pendaftaran administrasi kurang lebih dari 10 menit di waktu rame, kecepatan dan ketepatan diagnosa penyakit maupun keterbukaan informasi kepada pasien, begitupun sebaliknya pasien yang menyatakan kurang puas kepada petugas kesehatan yang memiliki kehandalan (reability) dimana pasien mengalami ketidak lengkapan persyaratan berkas administrasi dalam pelayanan kesehatan baik tingkat rujukan maupun dalam penggunaan kartu BPJS sehingga waktu pendaftaran administrasi terlambat/terhambat dari waktu menunggu 5-10 menit menjadi 1-2 jam di waktu rame dan ketidak sabaran pasien baik menunggu antrian maupun menunggu petugas kesehatan sehinga hal inilah yang membuat ketidak puasan pasien. Kualitas pelayanan pasien sangat berpengaruh positif terhadap kepuasan pasien rawat inap yang berarti makin meningkatnya pelayanan, maka akan meningkat pula kepuasan pasien, begitu juga terjadi sebaliknya.[16][17][18]

Sedangkan dari segi Jaminan (Assurance) diketahui pasien rawat inap di BLUD Rumah Sakit Umum Daerah Kabupaten Bombana yang menyatakan puas dengan petugas kesehatan yang memiliki jaminan (assurance) yaitu sebesar $80 \%$ dan pasien yang kurang puas dengan petugas yang memiliki daya tangga sebesar 7\%. Saputra dkk,[14] melaporkan bahwa ada hubungan bermakna antara Jaminan (Assurance) dengan kepuasan pasien ( $\rho$ value $=0,000 ; p<0,05$ ), dengan kata lain Jaminan (Assurance) dalam pelayanan berpengaruh terhadap kepuasan pasien, semakin tinggi kenyamanan maka semakin tinggi pula tingkat kepuasan pasien.

Hasil penelitian menunjukkan bahwa bahwa keterampilan perawat memberikan pelayanan sebagian besar responden menyatakan puas tentang keterampilan yang diberikan. Jawaban responden kurang puas bahwa masih ada perawat yang kurang terampil dana melaksanakan pelayanan keperawatan. Dari segi hubungan antara Fisik (Tangible) diketahui pasien rawat inap di BLUD Rumah Sakit Daerah Kabupaten Bombana yang menyatakan puas dengan pelayanan rumah sakit yang memiliki bukti fisik (tangible) yaitu sebesar $73 \%$ dan pasien yang kurang puas dengan pelayanan rumah sakit yang memiliki bukti fisik (tangible) yaitu sebesar 14\%. Yang memebahs tentang ketersediaan alat-alat yang canggih, suasana yang aman dilingkungan di rumah sakit, penampilan dokter dan perwat sewaktu bertemu dengan pasien yang sedang dirawat.

Begitupun sebaliknya pasien yang merasa kurang puas ini disebabkan sikap pasien atau keluarga pasien yang kurang menaati peraturan rumah sakit yang membuang sampah di sembarang tempat, pasien atau keluarga pasien yang kurang menjaga kebersihan kamar mandi, tidak menjaga kebersihan kamar inap perawatan. hal ini berdampak terhadap pasien baru yang melakukan perawatan rawat inap sehinga 
menimbulkan kesan tidak nyaman. Dan sebagian kecil petugas kesehatan kurang memperhatikan kebersihan lingkungan rumah sakit. Juwita dkk[19] pada pasien di Rumah Sakit Umum Daerah Tamiang Layang didapatkan hasil yaitu ada hubungan antara kualitas pelayanan kesehatan dimensi bukti fisik (tangible) dengan tingkat kepuasan pasien dengan $\rho$ value $=(0,001)$. Bukti fisik (tangible) dapat berupa ketersediaan sarana dan prasarana termasuk alat yang siap pakai serta penampilan karyawan /staf yang menyenangkan.

Selain itu, jika ditinjau hubungan antara Perhatian (Emphaty) dengan kepuasan pasien rawat inap memperlihatkan nilai $\rho$ value $=0.000<0,05$ maka $\mathrm{Ha}$ diterima dan $\mathrm{H}_{0}$ ditolak artinya ada hubungan yang bermakna antara perhatian (emphaty) dengan kepuasan pasien terhadap pelayanan kesehatan rawat inap di BLUD RSUD Kabupaten Bombana.

Hasil ini sejalan dengan Niswatul[13] di Puskesmas Blang Geulumpang Kabupaten Aceh Utara didapat hasil terdapat hubungan yang bermakna antara faktor perhatian (emphaty) dengan kepuasan pasien dengan nilai $\rho$ value $=0.007(p<0.05)$. Hasil ini diperkuat dari hasil pengamatan dan wawancara yang dilakukan peneliti, pasien yang menyatakan puas kepada pelayanan petugas kesehatan yang memeliki perhatian (emphaty) ini disebabkan pasien mengalami dan merasakan langsung sikap sopan santun atau kehatihatian petugas dalam menanyakan keadaan pasien, petugas memotivasi pasien, petugas dan pasien saling bertegur sapa dan memberikan senyuman, dan kesabaran petugas dalam menghadapi pasien keluhan pasien hal inilah yang membuat pasien nyaman terhadap petugas kesehatan, begitupun sebalinya[20][21].

Dari, sisi Daya Tanggap (Responsiviness) membuktikan bahwa ada hubungan yang bermakna antara daya tanggap (responsiviness) dengan kepuasan pasien terhadap pelayanan kesehatan rawat inap di BLUD RSUD Kabupaten Bombana, dibuktikan dengan nilai $\rho$ value $=0.000<0,05$. Hasil ini sejalan dengan Niswatul[13] di Puskesmas Blang Geulumpang Kabupaten Aceh Utara didapat hasil terdapat hubungan yang bermakna antara faktor daya tanggap (Responsiviness) dengan kepuasan pasien dengan $\rho$ value $=0.001(p<0.05)$. Hasil ini sejalan dengan Maulina dkk'[22] di unit rawat inap UPT puskesmas cibungbulang kabupaten bogor didapatkan hasil terdapat hubungan yang bermakna antara faktor responsiveness (daya tanggap) dengan kepuasaan pasien.

Oleh karena itu, Perilaku pelayanan diantaranya ditunjukkan sikap dokter dalam melayani pasien. Sikap yang ditunjukkan dengan tingkah laku hendaknya memenuhi norma yang dikehendaki oleh masyarakat terutama oleh penderitaan pasien dan keluarganya, menjalin hubungan yang baik dengan pasien dan keluarganya hingga timbul kepercayaan kepada dokter dan sebelaum memeriksa pasien sebaiknya dokter dan perawat memperkenalkan diri terlebih dahulu

\section{SIMPULAN}

Berdasarkan hasil analisis studi kasus dapat disimpulkan bahwa : (a) Terdapat hubungan yang bermakna antara kehandalan, jaminan (Assurance), bukti fisik (tangible), perhatian (emphaty), Daya Tanggap (responsiviness) dengan kepuasan pasien terhadap pelayanan kesehatan rawat inap di BLUD RSUD Kabupaten Bombana 2021 dengan nilai ( $\rho$ value $=$ $0.000<0,05)$. Pada Kajian ini jaminan dan empathy menjadi kriteria yang dominan terhadap penilaian kepuasan pasien yaitu sebanyak 68 orang yang setuju dan puas terhadap pelayanan yang di berikan petugas Badan Layanan Umum Daerah Rumah Sakit Umum Kabupaten Bombana. Saran untuk peneliti selanjutnya adalah memperdalam lanjutan yang berhubungan dengan kepuasan pasien.

\section{DAFTAR PUSTAKA}

[1] D. T. Pangerapan, O. E. L. I. Palandeng, and A Joy M Ratu, "Hubungan Antara Mutu Pelayanan Dengan Kepuasan Pasien Di Poliklinik Penyakit Dalam Rumah Sakit Umum Gmim Pancaran Kasih Manado," J. Kedokt. Klin., vol. 2, no. 1, pp. 9-18, 2018, [Online]. Available: https://ejournal.unsrat.ac.id/index.php/jkk/articl e/viewFile/18836/18386.

[2] A. Septiani, "Pengaruh Faktor-Faktor Kualitas Pelayanan terhadap Kepuasan Pasien di Instalasi Gawat Darurat RSUD Kabupaten Sumedang," Coopetition, vol. VII, no. Maret, pp. 1-21, 2016.

[3] Hardiansyah, Kualitas Pelayanan Publik. Yogyakarta: Gaya Media, 2011.

[4] I. M. N. I. N. Rinala, I Nyoman; Yudana, "Pengaruh Kualitas Pelayanan Akademik Terhadap Kepuasan Dan Loyalitas Mahasiswa Pada Sekolah Tinggi Pariwisata Nusa Dua Bali," e-Jurnal Progr. Pascasarj. Univ. Pendidik. Ganesha, vol. 4, pp. 112, 2013.

[5] F. Tjiptono and Diana, Total Quality Management. Yogyakarta: Penerbit Andi Offset, 2001.

[6] Parasuraman, Delivering Quality Service. New York: The Free Press, 2005.

[7] P. Kotler and Gary Armstrong, Principles of Marketing. Geneve: HEG, 2013.

[8] Supriyanto and Ernawati, Pemasaran Industri Jasa 
Kesehatan. Yogyakarta: CV Andi Offset, 2010.

[9] B. Suzanto, "Pengaruh Kualitas Jasa Pelayanan Terhadap Kepuasan Pasien Pada Rumah Sakit Umum Kota Banjar," J. Ekon. Bisnis Entrep., vol. 5, no. 1, pp. 26-28, 2011.

[10] J. Natassa and Afrizah, "Hubungan Mutu Pelayanan Dengan Kepuasan Pasien Di Ruang Rawat Inap Rumah Sakit Tentara Pekanbaru," Phot. J. Sain dan Kesehat., vol. 7, no. 02, pp. 9398, 2017, doi: 10.37859/jp.v7i02.512.

[11] S. Hertiana, "Analisis Harapan Dan Kepuasan Pasien Terhadap Mutu Pelayanan Kesehatan Dengan Metode Ipa (Importance Performance Analysis) Di Puskesmas Kartasura II Tahun 2009," Universitas Muhammadiyah Surakarta, 2009.

[12] S. Riyanto, A. Sutrisno, and H. Ali, "International Review of Management and Marketing The Impact of Working Motivation and Working Environment on Employees Performance in Indonesia Stock Exchange," Int. Rev. Manag. Mark., vol. 7, no. 3, pp. 342-348, 2017, [Online]. Available: http:www.econjournals.com.

[13] N. Khaira, "Hubungan Kualitas Pelayanan Kesehatan dengan Kepuasan Pasien di Puskesmas Blang Geulumpang Kabupaten Aceh Utara Tahun 2020," Universitas Muhammadiyah Aceh, 2020.

[14] C. Saputra, Y. Arif, and F. Yeni, "Andras Nursing Informatic System Application (Annisa) dalam Upaya Meningkatkan Pengetahuan Perawat tentang Dokumentasi Keperawatan," J. Keperawatan Silampari, vol. 4, no. 1, pp. 20-30, 2020, doi: 10.31539/jks.v4i1.1281.

[15] A. Latupono, M. A. Maidin, and A. Zulkifli, "Hubungan Mutu Pelayanan terhadap Kepuasan Pasien Rawat Jalan di RSUD Masohi Tahun 2014," J. JST Kesehat., vol. 5, no. 1, pp. 74-81, 2015.
[16] S. Sulaiman and A. Anggriani, "Hubungan Mutu Pelayanan Terhadap Kepuasan Pasien di Poli Fisioterapi RSU Siti Hajar," J. Endur., vol. 4, no. 2, p. 252, 2019, doi: 10.22216/jen.v4i2.3965.

[17] H. Mutiara, D. Mayasari, E. T. Fattima, and C. Saputri, "Hubungan Mutu Pelayanan Dengan Kepuasan Pasien Peserta BPJS di Ruang Rawat Inap Penyakit Dalam RSUD dr. H Abdul Moeloek," JK Unila I, vol. 2, pp. 31-36, 2018.

[18] Andoko, H. Norman, and Dewi Novalina, "Hubungan Mutu Pelayanan Terhadap Tingkat Kepuasan Pasien Rawat," Holistik J. Kesehat., vol. 12, no. 2, pp. 92-102, 2018.

[19] Y. Anggriani, A. Rianti, J. Pontoan, and Y. Juwita, "Analisis Efektivitas Terapi Antiretroviral Pada Pasien Hiv/Aids Rawat Jalandi Rsup Fatmawati Jakarta Tahun 2016," J. Ilm. Ibnu Sina Ilmu Farm. dan Kesehat., vol. 4, no. 1, pp. 9-18, 2019, doi: 10.36387/jiis.v4i1.212.

[20] Suparta, Haryono, and A. Kamsir, "Hubungan Mutu Pelayanan Terhadap Kepuasan Pasien Di Poli Umum Puskesmas Lompoe Kota Pare-Pare," J. IIm. Kesehat. Pencerah, vol. 7, no. 1, pp. 54-63, 2018.

[21] I. K. Rismayanti, Gunawan Bata Ilyas, "Pengaruh Mutu Pelayanan Terhadap Kepuasan Pasien Di Uptd Kesehatan Puskesmas Bojo Baru Kabupaten Barru," J. Kesehat. Masy. Terpadu, vol. 1, no. 2, pp. 85-102, 2018.

[22] L. Maulina, T. A. Madjid, and I. Chotimah, "Hubungan Mutu Pelayanan Kesehatan Dengan Kepuasan Pasien Peserta Bpjs Di Unit Rawat Inap Puskesmas Cibungbulang Kabupaten Bogor Tahun 2018," Promot. J. Mhs. Kesehat. Masy., vol. 2, no. 2, p. 130, 2019, doi: 10.32832/pro.v2i2.1798. 